ROCZNIKI TEOLOGICZNE

Tom LXVI, zeszyt 11 - 2019

DOI: http://dx.doi.org/10.18290/rt.2019.66.11-2

REV. PIOTR T. GOLISZEK

\title{
FOUNDATIONS OF PERSONAL MYSTAGOGY IN CATECHESIS
}

\begin{abstract}
A b s t r a c t. Mystagogy is a profound catechetical introduction into the mysteries of faith and into the incomprehensible mystery of God. Initiation is a special function that the Church performs through catechesis. It is mainly connected with the sacraments of Christian initiation; catechesis facilitates the understanding, and educates to the reception, of all the sacraments, introducing into the understanding and life of the Church, into the liturgy and prayer that supports the process of initiation. Christian initiation is a dynamic and personal event and as such it also requires introduction into the personal mystery. It is an introduction to the mystery of humanity; a formation to the true and profound human life. The introduction of the catechised into the personal mystery protects against the institutional and functional treatment of the Church, liturgy, the sacraments, and prayer. Mystagogy, therefore, is an introduction to the depths of God's worship and to the mystery of humanity.
\end{abstract}

Key words: person; personalism; relation; communication; community; catechesis; faith; education; initiation; mystagogy; mystery.

Christian initiation offered by catechesis is an integral initiation, ${ }^{1}$ which is expressed in the merger of the entire human person with Christ. Introducing man into the mystery of the Church and the mystery of liturgy and the sacraments is at the same time a process of man's personalization. It is an introduction which not only makes it possible to participate consciously

Rev. Piotr T. GoliszeK, PhD, dr. hab. - Chair of Catechetics of the Faculty of Theology, Catholic University of Lublin; address: Al. Unii Lubelskiej 15, 20-950 Lublin; e-mail: goliszek@kul.lublin.pl; p.goliszek@diecezja.lublin.pl

Ks. dr hab. PIOTR T. GoLISZEK - adiunkt Katedry Katechetyki Szczegółowej Wydziału Teologii KUL; adres: Al. Unii Lubelskiej 15, 20-950 Lublin; e-mail: goliszek@kul.lublin.pl; p.goliszek@diecezja.lublin.pl

${ }^{1}$ John PaUl II, Apostolic Exhortation Catechesi Tradendae, 16 October 1979, no. 21. 
in the mysteries of Christianity, but also enables one to become more personally involved in the inner life of the Holy Trinity. Thus, man's presence in the Church, participation in the liturgy, reception of the sacraments and personal address to God in prayer is neither magic, nor ritualistic legalism, nor external ritualism, but rather a mutual personal interpenetration of God and man. In these events, God realistically and personally meets man and includes him in his Communion Being. ${ }^{2}$

Initiation is therefore the highest stage in the complete personalization of human existence. Man is in a way "constructed" and thematized directly by the Divine Persons in the mysteries. Thus, a personalistic introduction to Christian mysteries in a sense "safeguards" catechesis against abstract and formalistic presentation of God, the Church, liturgy, the sacraments, and prayer. At the same time, it is worth bearing in mind that Christian initiation will be most effectively accomplished when we allow the mysteries of Christ's life to "enter" the personal life of the catechised and "penetrate" their personal worlds. This is possible under the personalistic approach, ${ }^{3}$ according to which a person is a relationship that is essentially directed towards God. Therefore, the ultimate condition for understanding the life of man and for making him/her happy and valuable, is the personal relationship with God. God is in the depths of the person in a constitutional and constituting manner. He gives man the gift which shapes him and organises him in his essence; this is a personal gift through which God offers the fullness of humanity to the human person. This means that a human person would not be a person without God, who continuously personalizes man. Consequently, it can be said that catechesis which serves Christian initiation makes man, in these Christian mysteries, not so much experience God; man in his personal dimension is the experience of God. ${ }^{4}$

\footnotetext{
${ }^{2}$ Cf. Joseph Ratzinger, Sakrament i misterium. Teologia liturgii, transl. A. Głos (Kraków: Wydawnictwo AA, 2011), 44.

3 Cf. Roman Murawski, "Katecheza jako głoszenie Chrystusa," Ateneum Kapłańskie 29(1997), 66-76.

${ }^{4}$ Cf. Carlos VAlverde, "Osoba we wspólnocie religijnej," in: IDEM, Antropologia filozoficzna, transl. G. Ostrowski (Poznań: Pallottinum, 1998), 378-379.
} 


\section{WHO IS THE PERSONAL MYSTERY?}

A person is the most mysterious being, hiding the greatest depth. This mystery should be respected because it implies that the person's experience is unique. ${ }^{5}$ What, then, does it mean that the person is a personal mystery? Each and every one as a person is unique among all the others. He is somebody unique and exceptional in his existence. He is unique in being a person. This singularity is founded on the exceptional closeness with God, who is a Person, one and only. ${ }^{6}$ Besides, the person is a mystery to himself. In a way, he hides "himself", thanks to which he is unique and inimitable. This hiding of a person determines the "being" of a man in his existence. Through this hiding, he is even more himself. Without a mystery, a person is not what he should be, that is, being-in-himself, a self-contained, indivisible and free being. Man in incapable of revealing himself completely. Man cannot reveal the full truth about himself. If it were possible, man would cease being-inhimself, a unique and free being, and would lose his unique sense. The mystery of the person is the essence of that person. This fact makes the person in his own essence a being for himself, i.e. is non-transferrable to others. One cannot offer one's person to others; one cannot transfer himself. The person can only have the ability to enter into relations with others, into a communion, never losing himself though, remaining himself, enriching others with himself and enriching himself with other persons. ${ }^{7}$

At the same time, it seems that the person "must" remain a mystery. Through mystery he possesses himself, disposes of himself and is what he should be, namely himself. "The person reveals the mystery and the mystery reveals the person, but also: the person protects the mystery and the mystery protects the person. Respect for the person is connected with respect for the mystery, which he or she hides in himself or herself." 8 Respect for this person's privacy also means respect for personal being. This is because it re-

\footnotetext{
${ }^{5}$ Cf. Grzegorz HoŁub, "Osoba ludzka: pomiędzy paradoksem a wieloaspektowością istnienia," in: Spór o osobe w świetle klasycznej koncepcji człowieka, ed. P.S. Mazur (Kraków: "Ignatianum," Wydawnictwo WAM, 2012), 188-189.

${ }^{6}$ Cf. Hans Urs von Balthasar, Teologika. Prawda świata, vol. 1. Transl. J. Zychowicz (Kraków: Wydawnictwo WAM, 2004), 97.

${ }^{7}$ Cf. Marek A. Kostur, "Osoba a wychowanie. Ujęcie z perspektywy personalistycznej," in: W kręgu inspiracji personalizmu etycznego, ed. P. Duchliński (Kraków: "Ignatianum," Wydawnictwo WAM, 2012), 305-307.

${ }^{8}$ Grzegorz BARTH, Hermeneutyka osoby (Lublin: Wydawnictwo KUL, 2013), 234.
} 
veals both the personal God and man as a person in their impenetrable mystery. Mystery, therefore, determines the direction of knowledge; then the mystery of the person is understood in its being accepted as a gift. In this way, each person should be received as a gift that is revealed but not lost. "The logic of the gift proves that a person does not keep his mystery for himself in order to remain with it, but to reveal it to others." key to understanding a person as a gift; love does not demand to embrace and know everything. Therefore, it is only through love that it becomes possible to know another person.

The person is revealed in communion with others. This encounter is always creative, because man achieves self-awareness and self-knowledge in communion with others. It is a relationship with someone who is equally selfaware and thus capable of offering himself to others. ${ }^{10}$ A person has the capacity to give himself and to enrich himself with another person and to enrich the other person through being human together. This interpersonal communion is based on the fact that the human person enriches himself by enriching others. He receives as much as he gives of himself and loses what he does not give to others. If he concentrates only on "having", he has to fight against others, and when he decides to "be" more, he enriches himself by giving himself to others. ${ }^{11}$

Giving of oneself to others is the ultimate love. This love takes nothing away from man, but creates him as a person. ${ }^{12}$ A unique personal mystery is taking place here: the more a person offers of himself, the more he is a person in-himself. The more he forgets about himself to help others, the more visibly he is himself. It must be made clear that at stake here is not piety, but rather ontic reality, which is tested in the experience of the properties of the human being (esse). Directed towards the good of the other person, love is the most genuine and fruitful relationship that can exist between persons. Each person can find himself only in another person. Only by

\footnotetext{
${ }^{9}$ Ibidem, 235.

${ }^{10}$ See Tadeusz STYCZEŃ, Objawiać osobę (Lublin: TN KUL, 2013).

${ }^{11}$ Cf. Carlos VAlverde, "W stronę nowej interpretacji osoby," in: IDEM, Antropologia filozoficzna, 346.

${ }^{12}$ Cf. BenedyKt XVI, Wstuchiwać się z catym Kościotem w stowo i wole Chrystusa. Homily delivered during the inauguration of the pontificate, Rome 24.05.2005 [online] [access: 12.12.2015]. Available online at:<http://www.opoka.org.pl/biblioteka/W/WP/benedykt_xvi/ho milie/inaug_piotra_24042005.html>.
} 
transcending oneself in search of "you" and "we" does one realize oneself, one's essence and one's own "being."13

\section{PERSONAL MYSTERY VS. INITIATION}

A question therefore arises as to why personal mystery is spoken about in the context of Christian initiation in catechesis. The introduction of the catechised into the mystery of the Church, into the mystery of liturgy, the sacraments and prayer is an introduction into a personal mystery, i.e. the mystery of God and man. God, by giving himself and saving man, offers man above all a new life and directs man towards himself. In this encounter between man and God, the human person begins to experience his "I" in the face of the "I" of God (I am), entering into an intimate personal relationship with God. At the same time, we cannot forget that the characteristic feature of mystagogical catechesis is to lead man to personally accept Christ as Lord and Saviour. ${ }^{14}$ The Holy Spirit is the source of this personal relationship with Christ. It is His Person who makes man experience his own self in relation to the "I" of Christ. The personal relationship to Christ is formed in the Holy Spirit, i.e. in the Person and through the Person. The Paraclete makes man meet and experience Christ as a living, real Person. ${ }^{15}$

The General Catechetical Directory explains moreover that the catechetical activity in the Church is primarily addressed to the human person. ${ }^{16}$ Therefore, catechetical ministry does not serve ideas or things, but remains in the service of the person and is addressed exclusively to him. The person is the ultimate subject of the catechetical reality and also the subject of the relationship with the supernatural world, which catechesis teaches and explains. Therefore, it can be said that catechesis is essentially personalistic, since it serves the Uncreated Persons and the created ones. The whole catechetical process takes place in the world of persons. For this reason, the methodological principle given by The General Catechetical Directory is identical to the one proposed by universalistic personalism. The Directory recommends

\footnotetext{
${ }^{13}$ Cf. C. VAlverde, "W stronę nowej interpretacji osoby," 348-349.

14 Cf. The Congregation for Clergy, General Directory for Catechesis (Poznań: Pallottinum, 1998), no. 67.

15 Cf. Franciszek BLACHNICKI, "Duch Święty a sakramenty," in: IDEM, Oblicza Ducha (Kraków: Wydawnictwo Światło-Życie, 2009), 121-122.

${ }^{16}$ Cf. General Directory for Catechesis, no. 116.
} 
that: "one should set off from God to come to Christ and vice versa; similarly, one can set off from the human person to come to God and vice versa." 17 Just like the ,person” is the starting point for personalism, it is also the person who is the starting point of the entire cognitive and methodological process. Thus, one can speak of a "world of the person" through which all the surrounding reality is interpreted. The person is characterized by extraordinary dynamics not only in relation to other people and the world, but also to the Divine Persons. The person is therefore an ontic relation "towards" another person, other persons and God.

Catechesis, striving to clarify the mystery of man in the light of the mystery of the Incarnate Word, does it through the prism and in the light of the person. "Not only does it show who God is, what his salvific plan is, but, as Jesus himself did, it also fully reveals man to man and allows him to know his highest calling." Therefore, catechesis reveals both the mystery of God and that of man. Love is known to have a special power to comprehend the mystery of man. Therefore, with love comes with the knowledge and understanding of mystery. God, who is love (1 John 4:8), knows man till the end. The mystery of man is revealed in God because Love removes the mystery without destroying the person. God is the Person par excellence and therefore His essence is incomprehensibility, which can only be "understood" by love, which explains all things. We can therefore say that the mystery of man is a reflection of the mystery of God. Just as the mystery of the human person was considered in the first section, by analogy the mystery of God must remain a mystery, because as a Person God covers all of himself. At this point the personalistic character of the initiation becomes clear. Catechesis, apart from the ritual and semiotic induction, completes the process of initiation through the introduction into the personal mystery of God and man. This is where the ultimate goal of catechesis - communion with Christ, or the human person being "embodied" into the Communion of the Divine Persons through Christ and in Christ - is achieved. M. Finke emphasizes this mystery-oriented and personalistic character when writing about catechesis that "is the initiation into the mystery of God who speaks to us, especially in Jesus Christ, in the Church." 18 This initiation into the mystery of God is

\footnotetext{
${ }^{17}$ Cf. General Directory for Catechesis, no. 118.

${ }^{18}$ Marian FINKE, "Odnowa katechetyczna. Zarys katechetyki kerygmatycznej," in: Pod tchnieniem Ducha Świętego. Wspótczesna myśl teologiczna, ed. M. Finke, C.S. Bartnik (Poznań-Warszawa-Lublin: Księgarnia św. Wojciecha, 1964), 588.
} 
a mutual penetration of the human person and the Divine Person. In this union, man fully realizes his humanity and renews himself as a person.

It is also worth emphasizing that the possibility of human communion with God stems from the fact that the person is relational. As a subject, every person is capable of talking and communicating and, consequently, of building interpersonal relations and a community. The interpersonal relationship is based on the openness of the person to others and for others. The interpersonal bond is born from a person for a person and from one person to another. Interpersonal communication is possible because the person has the ability to expose himself to others and share himself, without losing himself and his mystery. This kind of communication gives rise to dialogue. It is "placed" in what connects, what is real and what is good. It is not a matter of reaching a common position, but of an encounter. This meeting is invariably based on the "personal self," which is the source of understanding and community. Therefore, only the person is capable of communication and understanding and that is why the process is possible between persons.

\section{RELATIONALITY IN INITIATION}

The relationship between persons, the relationship to another person and to other people takes place in the best way in the community. This is because the essence of man is expressed in the fullest possible way in a community, in communion with another person and with the whole community. Co-existence with another person and with others attains its fullness in love. The one who loves exists to the full and reveals himself. Love is the most perfect form of the person. The more a man loves, the more fully his person expresses himself. Someone is the one who loves. Similarly, the one who does not love and cannot be for others, loses what he should be. The more a person loves, the more he exists, and vice versa: the more he is, the more he loves. ${ }^{19}$

Importantly, it was Jesus Christ who revealed the person to the full (1 Tim 2:5). Therefore, the person is the "name" which is first and foremost the attribute of God. By analogy, it is also attributed to man, who in this way receives a new quality and a unique status, namely: becomes a person. This new name indicates that man can enter into a direct relationship with God;

\footnotetext{
${ }^{19}$ Cf. C. VAlverde, "W stronę nowej interpretacji osoby," 344-345.
} 
without the category of the "person" the relationship between God and man would be impossible.

If man is able to relate to God, then he is also especially called to dialogue and partnership and to a personal response to God. The dialogic nature of the divine-human relationship brings man closer to a fuller understanding of his existence. He understands that he is summoned by his own name and, at the same time, called to answer. The name is not only a personal name, but something far higher. It reflects the very essence of man, i.e. his personhood. That is why God calls man by his name - "a new name [...] known only to the one who receives it" ( $\operatorname{Rev} 2: 17)$.

In this context, the meaning of the "new name," the sense of calling man a person, is revealed to man solely through an encounter with God. This means that man is a person because he is in relationship with God, who reveals himself to him. However, God does not only reveal the truth about Himself and man, but above all reveals Himself, reveals the mystery and remains a Mystery. At the same time, this mystery reveals God as a Person. This is also how Christ reveals God. Through Himself, Christ brings the Person of the Father and the Person of the Spirit closer to man, reveals them and leads to an encounter and dialogue with Them. ${ }^{20}$

An encounter with Christ demands a response from man, i.e. imitation in the sense of following in His footsteps in line with the personal order. ${ }^{21}$ Importantly, following in the footsteps of the Person of Christ on the one hand reveals God's infinity, and on the other hand shows the horizon of man's ken. Christ shows the catechised the direction and destination of human life. The total devotion of Christ and his obedience to God indicates that his relationship with God is an inspiration for man to accept dialogical thinking and acting. Thus, it serves as a signpost for understanding the person in his dialogical function. ${ }^{22}$ In Christ man reads the signpost reminding him that one's personal sense is revealed to the fullest when it is directed towards other people in the attitude of existential openness and dedication to them. No true personal being can exist without the communio. God is the paragon

\footnotetext{
${ }^{20}$ Cf. Jean DANiÉLOU, Trójca Święta i tajemnica egzystencji, transl. M. Tarnowska (Kraków: Wydawnictwo Znak, 1994), 39-40.

${ }^{21}$ See Andrzej DERDZIUK, "Chrystocentryzm personalistyczny," Roczniki Teologii Moralnej 1(59):2009, 41-45.

${ }^{22}$ Cf. Tadeusz PAnuś, Zasada wierności Bogu i człowiekowi i jej realizacja w polskiej katechizacji. Studium $w$ świetle Ramowego Programu Katechizacji funkcjonujacego w latach 1971-2001 (Kraków: Wydawnictwo UNUM, 2001), 337.
} 
and the ultimate form of the communio. The Divine Persons define themselves by being towards one another. "Being towards" is the core of the divinity of the Father, the Son and the Spirit. Christ reveals the relationality in that he is completely the Son, directed and devoted to the Father, ${ }^{23}$ through to his offering his own life on the cross. In Christ Christianity was offered the novelty of personalistic thinking, expressed in the mystery of the personal being. ${ }^{24}$ The person realises himself via transcending himself towards another person and through this he develops himself.

\section{INITIATION INTO THE PERSONAL MYSTERY}

The above reflections seem to account for why we need a reference to the personal mystery in mystagogy. Faced with God, man becomes aware of His Mystery and at the same time realises that he has an inherent likeness to God, which calls for continuous implementation. ${ }^{25}$ This, in turn, makes him pursue God and as a result he is in a living communion with God. Everything, however, takes place on the inter-personal level of relations. Without the awareness of "being a person" and without the desire to "become a person," communion with Christ, to which catechesis leads man, would be impossible.

The whole process of initiation consists in man's being "embodied" in his personal being into the transcendent Reality of the Divine Persons. The personal mystery is the key principle of the communion of God and man. It is moreover the principal process of developing personhood. Without the mystery of the person, neither man as a person nor God as a person can be understood. Initiation, on the one hand, is the personal union of man with God and, on the other hand, through participation in sacred mysteries, man, in the presence of Christ, brings out his person from being closed in his "I." In effect, he opens up the "I" hidden within himself to an inner communion with Christ Jesus, who gave himself to everyone. Thus, being present in the community of the Church and participating in the liturgy and the sacraments is no longer merely a personal experience. In a community, not only does

\footnotetext{
${ }^{23}$ Cf. Franciszek BLACHNICKI, Chrystus Stuga świattem Kościoła (Kraków: Wydawnictwo Światło-Życie, 2007), 28-29.

${ }^{24}$ Joseph RAtZinger, “Znaczenie osoby w teologii,” Personalizm 8(2005), 40.

${ }^{25}$ Cf. Angelo Scola, Osoba ludzka. Antropologia teologiczna, transl. L. Balter (Poznań: Pallottinum, 2005), 49.
} 
man unite with others in the role shared by the other participants, but also the individual persons unite in their being and only then do we deal with a communio personarum. ${ }^{26}$ While liturgy does contain some "role division," the person fulfils his "role" when they abandon their role to personally, without a veil, merge with Christ, thanks to which a space opens up in a human being in which as a person it can "touch" himself in his own being. This means that a person is able to come out of himself and unite with God in order to fully and deeply understand himself. Participation in God is the highest measure of human existence, the greatest level of human personalization. Consequently, the introduction of the catechised into the personal mystery is tantamount to breaking functionalism in liturgy and sacraments. Importantly, it has much more to do with fidelity to the person: the Person of Christ, the Mystical Person of the Church and the human person than with the ritualistic and symbolic treatment of liturgical ceremonies. ${ }^{27}$

The initiation that catechesis undertakes is the culmination of such a personal communion with Christ, where the person, through the sacrament of the Church and the holy sacraments, becomes a sign of God's presence, God's icon striving to "be a person" in God's likeness. It is also then that the personalization of man is accomplished as man is part and parcel of the communion of the Persons of the Triune God. It is God who becomes the heart of the human personality and enters into personal contact with it. Therefore, the identification of subjects is the prerequisite for the communion of man with Christ - the objective of catechesis - the communion of both the personal worlds of God and man. When man flees from a personal bond with God and remains only on the level of fidelity to doctrine itself, he seeks other absolutes. Yet the relationship between God and man is one of love and it cannot be any different. However, this is only possible between persons and through personal communion. ${ }^{28}$ "Full humanity is achieved only as a person in such a way that one can participate in the Trinitarian life of God. [...] Communion is the essence of God and therefore the essence of the human person." ${ }^{29}$ Thus communion is not only the community of God and man, but more so a mutual self-giving of God to man and self-offering of man to God. Com-

\footnotetext{
${ }^{26}$ JOSEPH RATZINGER - BENEDYKT XVI, Święto wiary. O teologii mszy świętej, transl. J. Merecki (Kraków: Wydawnictwo Salwator, 2006), 64-65.

${ }^{27}$ Cf. Bogumił GACKA, Znaczenie osoby w teologii Josepha Ratzingera - Benedykta XVI (Warszawa: Wydawnictwo UKSW, 2010), 239-240.

${ }^{28}$ Cf. C. VAlverde, Osoba we wspólnocie religijnej, 383.

${ }^{29}$ G. BARTH, Hermeneutyka osoby, 162.
} 
munion prevents man from focusing on himself only; it directs man towards God and by extension towards a unity with all Christians. The Person of Christ is seen here as the communio of the personal worlds of God and man. Therefore ,the Christian esse in Christ has a personalistic and dialogic structure." ${ }^{30}$ Personhood is, then, the only way of comprehending the Tri-Personal God and of referencing Him, as well as a path of interpersonal relations. Thus catechesis engages the entire being of the human person, leading him to a communion with Jesus Christ.

\section{MARY AS THE PARAGON OF THE MYSTERY OF THE PERSON}

In addition to the most important model of the Person of Jesus Christ, catechesis treats the Person Mary as another paragon of perfect humanity and a fulfilled person. ${ }^{31}$ She is shown as the ideal of religious perfection, obedience, humility, devotion to God, life in truth and simplicity. ${ }^{32}$ As a consequence, catechesis in its function of Christian initiation, introducing into the personal mystery, should appreciate the Marian aspect, thanks to which the catechised ,receive in the person and examples of Mary a common reference point for their faith [...], finding in the Mother of God an example to follow." 33 Moreover, Marian catechesis allows the catechised to see that man can attain fulfilment in life by entrusting himself completely to God and engaging in spiritual matters, just as Mary Immaculate did. In the person of Mary, the catechised receive a model of deep personal union with the Persons of the Trinity. Mary exists in a special relationship with each of the Persons, which creates Her unique personality. Yahweh makes the young woman of Nazareth the most beautiful of his Daughters, who shines on the horizon of the entire "pre-Jesus" history of salvation with the radiance of personal perfection. She then appears in the "history of Jesus" as Mother in relation to her Son. Mary's maternal and compassionate love for Jesus is a perfect unity

\footnotetext{
${ }^{30}$ Franciszek BLACHNICKI, "Zasady personalistycznej koncepcji katechezy," in: Katechetyka fundamentalna. Pisma Katechetyczne, vol. 2, ed. M. Marczewski, R. Murawski, K. Misiaszek (Warszawa: Wydawnictwo Salezjańskie, 2006), 126.

${ }^{31}$ Cf. Marian ZAJAc, Katecheza maryjna w Polsce w latach 1905-2005 (Lublin: Wydawnictwo KUL, 2006), 326-327.

32 Cf. Marek JAGODZIŃSKI, "Komunijna antropologia maryjna," in: IDEM, Antropologia komunijna (Lublin: Wydawnictwo KUL, 2015), 143.

${ }^{33}$ M. ZAJAc, Katecheza maryjna $w$ Polsce $w$ latach 1905-2005, 356.
} 
of persons. In the "post-Jesus history," Mary, being the spouse of the Holy Spirit, "is simply the mother of the members of Christ, because her love makes the faithful, who are members of this Head, be born in the Church." ${ }^{34}$ Each of these accounts shows a unique aspect of Mary's personal perfection. She is the gateway through which the Holy Trinity enters the world. Therefore, in the Trinitarian Communion, her Person is filled through the Holy Spirit with the grace of God and becomes open to co-creation with Him, so that she becomes "a reflection of the faith of the Church" 35 and the Mother of the Church.

We should moreover emphasise in the context of initiating the catechised into the personal mystery that Marian catechesis helps us see "Mary as the Person in herself. [...] Mary is first of all the Mystery of the Person, Light in itself, someone full of herself. She is Someone personal, an Individual of unlimited horizons of inner life, a miracle of creation." ${ }^{36}$ In the Person of Mary the catechised are granted an exemplar of being the human person and the paragon of a Full Person. ${ }^{37}$ In their friendship with Mary, or rather in her Person, they discover the true purpose and meaning of life, that is, union with God, moral perfection and purest love. She is moreover "a sign of the moral transformation of our natural humanity into the humanity of the person." 38 The Church, taking Mary as an example, develops, sanctifies and fosters the personal bond of man and God through catechesis.

Initiation into the personal mystery in the Person of Mary receives the Icon of a concrete and fulfilled Person. In Mysterium Mariae the catechised are offered "a sacramental sign," i.e. an embodiment of Love, Mercy, Communion with the Trinity, the offering of life to God, ecclesial communion, a perfect image of God in man. The mystery of the Person of Mary in the mystagogical catechesis supports a genuine following of Christ and the understanding of the personal mystery, a reflection of God's mystery. This is precisely the aim of catechesis: to enable man to be the most magnificent and fullest reflection of Christ, true God and true Man. Ultimately, therefore, we

\footnotetext{
34 The Second Vatican Council, Lumen Gentium, 21 December 1964, no. 53.

${ }^{35}$ M. JAGODZIŃSKI, "Komunijna antropologia maryjna," 143.

${ }^{36}$ Czesław S. BARTNIK, Dogmatyka katolicka, vol. 2 (Lublin: Wydawnictwo KUL, 2003), 288.

${ }^{37}$ See Paweł Mąkosa, "Maryja wzorem dobroci i miłości dla chrześcijanina," in: Miłość na nowo odkryta, ed. W. Przygoda, J. Karbownik (Radom: Polskie Wydawnictwo Encyklopedyczne, Skarżysko-Kamienna: Sanktuarium Matki Bożej Ostrobramskiej, 2007), 101-112.

38 C.S. BARTNIK, Dogmatyka katolicka, vol. 2, 291.
} 
may say that catechesis is the initiation into the depth of the mystery of God and the mystery of the human person.

Christian initiation is primarily a mystery event, which consists in the embodiment of man in his personal being in the transcendent Reality of the Divine Persons. It is an ontic relationship in which the Mystery of God permeates the mystery of man, i.e. God offers himself for the salvation of man. The personal mystery is a key principle of the communion between God and man. Without reference to the fact of the person and the category of the person, there would be no way of communication and communion. Only the person gives the fullest opportunity and at the same time the reality of the encounter and union of man and God. Christian initiation must therefore take place in the light of personal mystery, since the ecclesial, liturgical and sacramental communio with God involves personal co-existence. Moreover, communion with God and with other people is not only a community, but more the self-giving of God and the selfgiving of man in the area of personal life. Therefore, the classic Christian initiation must be complemented by an introduction into personal mystery; that is, catechesis, apart from the ritual and semiotic induction, must complement the process of initiation by the introduction into the personal mystery of God and man. This will prevent a merely institutional and hierarchical understanding of the Church and an instrumental and functional treatment of liturgy and the sacraments. It is much more about fidelity to the person: the Person of Christ, the Mystical Person and the human person than the ritual-symbolic treatment of the mysteries of the Church. Initiation is above all to lead to the communion with Jesus, where the catechised person, through the sacrament of the Church and the holy sacraments, co-exists with God the Father through Jesus Christ in the Holy Spirit.

\section{BIBLIOGRAPHY}

Balthasar, Hans Urs von. Teologika. Prawda świata. Vol. 1. Transl. J. Zychowicz. Kraków: Wydawnictwo WAM, 2004.

BARTH, Grzegorz. Hermeneutyka osoby. Lublin: Wydawnictwo KUL, 2013.

BARTNIK, Czesław S. Dogmatyka katolicka. Vol. 2. Lublin: Wydawnictwo KUL, 2003. 
BENEDYKT XVI. Wstuchiwać się z całym Kościotem w stowo i wole Chrystusa. Homily delivered during the inauguration of the pontificate, Rome 24.05.2005 [online] [access: 12.12. 2015]. Available online at:<http://www.opoka.org.pl/biblioteka/W/WP/benedykt_xvi/homi lie/inaug_piotra_24042005.html>.

BlachNICKI, Franciszek. Chrystus Stuga świattem Kościoła. Kraków: Wydawnictwo ŚwiatłoŻycie, 2007.

BLACHNICKI, Franciszek. "Duch Święty a sakramenty." In: IDEM. Oblicza Ducha, 120-127. Kraków: Wydawnictwo Światło-Życie, 2009.

BLACHNICKI, Franciszek. "Zasady personalistycznej koncepcji katechezy." In: Katechetyka fundamentalna. Pisma Katechetyczne. Vol. 2. Ed. M. Marczewski, R. Murawski, K. Misiaszek, 124-130. Warszawa: Wydawnictwo Salezjańskie, 2006.

DaniÉLou, Jean. Trójca Święta i tajemnica egzystencji. Transl. M. Tarnowska. Kraków: Wydawnictwo Znak, 1994.

DERDZIUK, Andrzej. "Chrystocentryzm personalistyczny," Roczniki Teologii Moralnej 1(59):2009, 41-45.

FINKE, Marian. "Odnowa katechetyczna. Zarys katechetyki kerygmatycznej." In: Pod tchnieniem Ducha Świętego. Wspótczesna myśl teologiczna. Ed. IDEM, M. Finke, Cz.S. Bartnik, 559-590. Poznań-Warszawa-Lublin: Księgarnia św. Wojciecha, 1964.

GACKA, Bogumił. Znaczenie osoby w teologii Josepha Ratzingera - Benedykta XVI. Warszawa: Wydawnictwo UKSW, 2010.

HoŁUB, Grzegorz. "Osoba ludzka: pomiędzy paradoksem a wieloaspektowością istnienia." In: Spór o osobę w świetle klasycznej koncepcji człowieka. Ed. P.S. Mazur, 185-205. Kraków: "Ignatianum," Wydawnictwo WAM, 2012.

JAGODZIŃSKI, Marek. "Komunijna antropologia maryjna." In: IDEM. Antropologia komunijna. Lublin: Wydawnictwo KUL, 2015.

John Paul II. Apostolic Exhortation Catechesi Tradendae, 16 October 1979.

Kostur, Marek A. "Osoba a wychowanie. Ujęcie z perspektywy personalistycznej.” In: $W \mathrm{kre}$ gu inspiracji personalizmu etycznego. Ed. P. Duchliński, 301-317. Kraków: "Ignatianum," Wydawnictwo WAM, 2012.

MĄKOSA, Paweł. "Maryja wzorem dobroci i miłości dla chrześcijanina.” In: Miłość na nowo odkryta. Ed. W. Przygoda, J. Karbownik, 101-112. Radom: Polskie Wydawnictwo Encyklopedyczne, Skarżysko-Kamienna: Sanktuarium Matki Bożej Ostrobramskiej, 2007.

MURAWSKI, Roman. "Katecheza jako głoszenie Chrystusa.” Ateneum Kapłańskie 29(1997), 66-76.

PANuś, Tadeusz. Zasada wierności Bogu i człowiekowi i jej realizacja w polskiej katechizacji. Studium w świetle Ramowego Programu Katechizacji funkcjonujacego w latach 1971-2001. Kraków: Wydawnictwo UNUM, 2001.

RATZINGER, Joseph - BENEDYKT XVI. Święto wiary. O teologii mszy świętej. Transl. J. Merecki. Kraków: Wydawnictwo Salwator, 2006.

RATZINGER, Joseph. Sakrament i misterium. Teologia liturgii. Transl. A. Głos. Kraków: Wydawnictwo AA, 2011.

RAtZINGer, Joseph. "Znaczenie osoby w teologii." Personalizm 8(2005), 33-48.

ScolA, Angelo. Osoba ludzka. Antropologia teologiczna. Transl. L. Balter. Poznań: Pallottinum, 2005.

STYCZEŃ, Tadeusz. Objawiać osobę. Lublin: TN KUL, 2013.

The Congregation for Clergy. General Directory for Catechesis. Poznań: Pallottinum, 1998.

The SeCond Vatican Council. Lumen Gentium, 21 December 1964.

VALverde, Carlos. Antropologia filozoficzna. Transl. G. Ostrowski. Poznań: Pallottinum, 1998.

ZAJĄC, Marian. Katecheza maryjna $w$ Polsce $w$ latach 1905-2005. Lublin: Wydawnictwo KUL, 2006. 
PODSTAWY MYSTAGOGII OSOBISTEJ W KATECHEZIE

S t r e s z c z e n i e

Mistagogia jest pogłębionym katechetycznym wprowadzeniem w misteria wiary oraz w niepojęte misterium Boga. Wtajemniczenie jest szczególną funkcją, którą realizuje Kościół za pośrednictwem katechezy. Wiąże się ona głównie z sakramentami wtajemniczenia chrześcijańskiego, przy czym katecheza przybliża rozumienie i wychowuje do przyjęcia wszystkich sakramentów, wprowadza w rozumienie i życie Kościoła, wprowadza w liturgię oraz modlitwę, która wspiera proces wtajemniczenia. Wtajemniczenie chrześcijańskie jest wydarzeniem dynamicznym i osobowym, dlatego wymaga również wchodzenia w misterium osobowe, bowiem jest wprowadzeniem w misterium człowieczeństwa, formacją do prawdziwego i przeżywanego bycia człowiekiem. Wprowadzenie wychowanków w misterium osobowe chroni przed instytucjonalno-funkcjonalnym traktowaniem Kościoła, liturgii, sakramentów oraz modlitwy. Mistagogia jest więc wprowadzeniem w głębię kultu Bożego, a także w tajemnicę człowieczeństwa.

Słowa kluczowe: osoba; personalizm; relacja; komunikacja; wspólnota; katecheza; wiara; wychowanie; wtajemniczenie; mistagogia; tajemnica. 